\title{
MODEL AND CHARACTERISTICS OF MICRO FINANCE INSTITUTIONS BASED ON SME WOMEN IN BATU CITY
}

\author{
Ike Kusdyah Rachmawati *)
}

\begin{abstract}
The development of SMEs is largely determined by the existence of MFIs that offer financing models are diverse. It can be said that MFIs become a partner of SMEs in this regard as a financial services provider, through diverse financing models. But on the other hand the diversity of financing models offered by MFIs have not been fully able to be utilized. This study used exploratory research, descriptive, experimental and applied research conducted in stages for the development of a comprehensive model of microfinance accommodative Informants determined based on the information needs. Using a descriptive and qualitative analysis of the MFI deliberately selected examples illustrate the following: (A) The existence of MFIs is recognized community has a strategic role as an intermediary in economic activity that has not affordable public services of banking institutions / conventional banks; (B) service MFIs have demonstrated success, but success can still be in business economics. Skim MFI lending to businesses has not received the priority, it is characterized by a relatively small ceiling (budget allocation) to support farming, which is less than $10 \%$ of the total ceiling of MFIs; (C) A critical factor in the development of the agricultural sector MFI lies in the institutional legality, capability management, seed capital support, the economic viability of farming, farm characteristics and technical assistance clients / service users MFIs; (D) To initiate the growth and development of agricultural MFIs needed guidance enhanced capabilities for HR candidates MFI managers, support the strengthening of capital and technical assistance to customers of credit users.
\end{abstract}

Keywords: Financial Institutions Micro, Small Business Micro

\section{INTRODUCTION}

\subsection{Research Background}

In order to accelerate the development of economic clusters cluster-based rural economic potential, the Community Empowerment Board of East Java Province in 2006, has launched the Economic Development Program Region which is the program as the action of the formation of regional productive economy that emphasizes economic development based on local economic potential of rural (Bapemas, 2007), as well as specially designed using the approach of productive economic region emphasis on utilization of local economic resources that focus on interrelationships and dependencies between actors in a network of production to services and innovation development efforts (Eko Aristanto, 2007). Utilization and development potential of natural resources is absolutely necessary in the economic development of a region (Carunia, 1997; Abbas Effendi, 2004).

By paying attention to these conditions and characteristics of the activities that have a tendency to empower micro businesses at a local level, we need the presence of microfinance institutions that have value alignments to micro enterprises, to be able to help in addressing the issues of business (ie capital) and technical assistance business management (Chotim, EE and Handayani, AD (2003). By considering the conditions and characteristics of the activities that have a tendency to empower micro businesses at a local level, we need the presence of microfinance institutions that have value alignments to micro enterprises, to be able to help in addressing the issues of business (namely capital ) and technical assistance business management (Chotim, EE and Handayani, AD (2003). under these conditions, this study will examine and formulate a model of microfinance institutions accommodating in developing economic clusters based on local economic potential in East Java Province 


\subsection{Research Problem}

Based on the above points of thought, researcher are interested to understand the constraint and the possibility of development of the micro finance.

\subsection{Research Purpose}

The purpose of this study is:

1. Analyze the constraints and barriers to underdevelopment in the presence of microfinance institutions based micro enterprises women of the districts in the Kota Batu.

2. Analyze and anticipate the possibility of economic and social phenomena as the impact of the development of micro-financial agency and improve access layer based women's micro business districts in Kota Batu

3. Formulate a development model of microfinance institutions accommodating in an effort to improve women based micro-enterprise districts in the city

\section{THEORETICAL FRAMEWORK}

\subsection{Theoretical Framework}

Financial institutions in this paper is a financial institution for a group Micro. Growth of Microfinance Institutions in Indonesia an estimated 30 percent in 2008. Siu (2001) explains that the MFIs are institutions that provide financial services to poor and low-income families (as well as their microscale business activities), enabling them to better manage their risks, achieve a consistent pattern of consumption, and develop its economic base.

\subsubsection{Womens Empowerment Program Objectives}

According to Rian Nugroho (2008: 164), the goal of women's empowerment program are:

a. Improving women's ability to engage in development programs, as active participation (subject) in order to not only become the object pembagunan as happened during this time

b. Improving the ability of women in leadership, to improve the bargaining position and involvement in each development well as planners, implementers

c. Monitoring and evaluation of activities

d. Improving the ability of women to manage household scale enterprises, small industries and large industries to support the promotion of household needs, as well as to productive employment opportunities and independent

e. Enhancing the role and function of women's organizations at the local level as a forum for the empowerment of women in order to be actively involved in the development program in the region of residence

\subsubsection{Definition of SME}

SMEs are the picture of the morphology of the SMEs concerned seen from the aspect of business and entrepreneurial nature of the SME entrepreneurs. From the aspect of the business profiles of SMEs can be seen from its ability to create added value of products produced, the efficient use of capital, and profits. While aspects of the development of SMEs Profile can be viewed on the ability to utilize waste materials, ability in employment and ability to contribute to the Gross Domestic Product (GDP).

In accordance with Law number 20/2008 on Micro, Small and Medium Enterprises (SMEs):

a. Micro is a productive enterprise belonging to individuals and / or entities that meet the criteria of individual businesses Micro as stipulated in this Law.

b. Small Business is an economic enterprise productive stand-alone, conducted by an individual or business entity that is not a subsidiary or branch of the company is not owned, controlled, or be a part either directly or indirectly from medium or large businesses that meet Small Business criteria referred to in this Act

c. Medium Enterprises is a productive economic activities that stand alone, carried out by an individual or business entity that is not subsidiaries or branches of companies owned, controlled, or 
be a part either directly or indirectly by the Small Business or large enterprise with the amount of wealth net or annual sales revenue as stipulated

Table 1 Criteria for SMEs According to Law

\begin{tabular}{|c|c|c|}
\hline No & Asset & Omzet (Million) \\
\hline 1 & Micro & Max 50>500.000.000 \\
\hline 2 & Small & $>50>500-2.5 \mathrm{M}$ \\
\hline 3 & Medium & $>500>2.5 \mathrm{M}-50 \mathrm{M}$ \\
\hline
\end{tabular}

Source : Processed

\subsubsection{Characteristics Small Business}

According to the characteristics of small businesses (Tambunan, 2002: 166) characteristics inherent advantages and disadvantages of SMEs is the SME itself. Some of the advantages of the SMEs are as follows:

1. Durability

2. Solid works

3. Special Expertise

4. Type of product

5. The linkage with other sectors

6. Capital

Characteristics of small businesses by Soeharto Prawirokusumo (2010: 48-49).

1. Small businesses are usually managed by their owners so-called owner-manager who usually acts as the leader who gives direction to some of the staff were not too many and not specialized to run the business. They called a management team that usually comes from family members, relatives or close friends.

2. Small businesses usually only have a single product line is not diversification. The volume of business is relatively small.

3. Responsible for decision making is usually held by a single person and less authorizing others.

4. The relationship between the management of the work is very close.

5. Usually a business organization in the absence of functional specialization.

6. In reporting system also did not rise.

7. Less has long term planning.

8. Usually not go public.

9. More oriented to survival for an owner's equity of the profit maximum.

10. Not dominant in the market

\subsubsection{Barriers experienced by SMEs in general}

The weaknesses of SMEs are reflected on the constraints faced by the business. Constraints commonly experienced by SMEs is the lack of capital, difficulties in marketing and supply of raw materials, knowledge is minimal about the world of business, limited mastery of technology, quality of human resources (formal education) is low, financial management is not good, not the division of tasks clearly, and often rely on family members as unpaid workers (Tambunan, 2002: 169).

1. There is no synergy synergy between government, banks, and state-owned enterprises with financing schemes uniform and control the rhythm that the development of SMEs can run well, not sporadic, and no overlap between the existing program

2. The issue of technology and product innovation. These problems become a classic problem MSME entrepreneurs. Impact, the SMEs often confusion when dealing with product expansion of factories larger and well-established. "If there is no technological approach and growth of a culture of innovation, SMEs will sooner or later die. At least SMEs will be difficult to develop large and 
forever so players medioker medium alias. In fact, SME-SME dealing with big business very sensitive technology and innovation, making it more efficient and more able to follow the changes in the market

3. Market research. During this time, SMEs barely supported by adequate market research related promotional model, market opportunities, competitors, substitutes and complementary to the products of young entrepreneurs, consumer tastes, market trends and other external factors. These conditions make the business expansion of SMEs is very limited. Without the support of market research, it is difficult for entrepreneurs to be able to know what the market needs. "Together governments and business world, the future involvement of universities should be intensified to conduct market research. It took a kind of market intelligence.

4. Inefficiency. SMEs do not have an optimum level of efficiency because it is not able to create economies of scale. Productivity level Total (TPT) large businesses are solid capital reached 170 times TPT small businesses. While mid-sized businesses have three times TPT small businesses. It shows how SMEs are just great in terms of employment and the number of business units, but in terms of scale and value of their business with large companies is far less capital intensive. TPT itself is a way of measuring business performance by calculating the value added per job opportunities are created.

\subsubsection{The Principle of The MFI}

There are seven (7) principles to be used as a reference when buildingMFI agriculture, namely:

1. Meet the principles of necessity, means that MFIs need to be cultivated on the farm only potential locations where farmers need support facilitation of capital, and there has been no financial services institutions in that location. Thus the MFI will provide greater benefits for local communities.

2. Be flexible, in the sense that fostered MFIs should be adapted to local conditions and culture.

3. Participatory. Growing MFIs should involve farmers in the local environment, so in addition to accommodate the aspirations of farmers, built participatory development will be able to build a sense of caring and ownership as well as the process through working together.

4. Accommodating. In this case the MFI should prioritize the fulfillment of customers' needs. Requirements for access to MFIs compiled so as to open up the widest opportunity for address the needs of farmers with the minimum requirements completeness owned by farmers.

5. Reinforcement. That is, although the establishment and development of MFIs providing farm capital, but not to create dependency but should $\mathrm{m}$ principle the latter is sustainability. The emphasis is on the ability of organizations sustainability of MFIs to continue running, even if there is no intervention agencies or government officials and private sector support. MFIs should be oriented towards the seven functional able to enhance the institutional capacity building of farmer groups.

6. Partnership. In this case the formation and development of MFIs conducted involving the various stakeholders (stakeholders), as a provider of production, figures farming communities, businesses, universities, and sectoral institutions involved in each activity greater improvement degrees of social welfare of all members of the farming communit

\subsubsection{Stages Formation of MFIs}

To get the operationalization of MFIs can conducted through at least six stages:

1. Assessment location and mapping needs. The location meets the criteria required by local authorities, cooperative, easy to reach, and support high success;

2. Selection Phase feasibility farmer groups;

3. Phase socialization of MFIs;

4. Start / Formation Organization of MFIs;

5. Phase Operationalization / Implementation MFIs. At this stage MFIs began marketing

6. To the farming communities around the region;

7. The final phase is the development of MFIs 


\subsubsection{Model MFIs}

Services to microfinance is not new, and still present in the lower and medium communities. In this section we will present several models of MFIs and various types of services provided to micro enterprises or low-income communities. MFI is used for the type of institutions offering microfinance services that are not fully in the formal regulation of the banking sector. Various models of microfinance institutions as follows:

1. Poverty-Focused Development Banks ie Forms bank with the professional staff and have access to the administrative decision independent of its funds lent to individuals or a group of affluent societies is limited.

2. Village Banks that loan funds are provided by an external agency for local community-based organizations, which can be legally registered or not. Function and overall banking transactions managed by those organizations that make up the team supervision and approval of the loan.

3. Thrift and Credit Co-operatives (TCCs) and Credit Unions (CUS) is a membership organization registered formally regulated by government regulations. An organization formed by a group of people who have a common bond (eg living in the same community or working in the same company) agreed to save money together and lend at a low interest rate, or use it for purposes or projects shared.

4. Intermediary NGO Programmes which facilitate relationships among low-income groups in micro enterprises or low-income communities with the formal financial system. They do delivery, assistance for filing, training, technical assistance, and guarantee for financial service providers reduce costs and risks of the target beneficiaries of the poor.

Some examples of cases of successful microfinance model is as follows:

1. The Grameen Bank is an example of successful experience that begins with informal loan to a group of poor people. It started to help people who do not own land in Bangladesh to get a loan. This program has been successful as these communities are cohesive (they both follow the landless) and was formed based on the principle of volunteerism.

2. Non Government Organization (NGO). NGO approach is also classified as informal and tend to adapt the model of Grameen principle. These models are usually formed based on gender or sectoral, such as women's societies, farmers' groups, trade unions, etc. For example, in Ghana and Gambia, most successful micro-credit program is managed by financial associations of women.

3. Esusu is a revolving loan scheme in Nigeria and spread to most of the State-negafa in West Africa as informal micro-credit program. The group was formed to run the scheme rolling voluntary. Group members contributed money to the number of fixed time periods are regular. In each of these periods, a member of the group collects all contributions from all members. Each member will get a turn obtain funding contributions until the cycle is complete, and then can begin again.

\subsubsection{MFIs Model-Based Community}

Model microfinance institutions have the primary task of lending to small- or low-income people and the environment familiar with the funding agency. Practically speaking, microfinance institutions provide financial services to the business trust on the basis of repayments. With this view shows that financial institutions based kumunitas as a form of financial services to the micro enterprises with loan formula standards for micro-enterprises. Maskur (2005) describes a variety of additional services to microenterprises MFI successfully executed in Bangladesh. Research results Research and Development Agency of East Java Province in 2005 shows a model of feeder Point with the features without collateral and low interest rate, small loans as a funding option that interested SMEs.

The results of the research community-based microfinance institutions are lending institutions that formula micro enterprises in the group's trust with a large pattern as a reference loan repayment installments. The results showed microfinance institutions provide community-based requirements developed with the following basic conditions: 
1. Trust

2. Loans formula group responsibility

3. Without collateral

4. Micro Entrepreneur known Microfinance Institutions

5. Great refund as a loan basis (activity ratio)

6. Micro known surroundings

The results also show that micro businesses are still dealing with high informal financial institutions and the number of micro-enterprises are able to build real sector, micro-enterprises can be developed with high flexibility and loans granted by the formula group responsibility. For the Government of Indonesia and Bank Indonesia to draft microenterprise sector loans not formally program, provided that:

1. Formal Microfinance Institutions need to side with Micro

2. The business loans with no collateral and liability scheme

3. Channelling funds to micro loans short term

4. Financial institutions developed Micro surrounding neighborhood known Model-based women's Microfinance Institutions

The model of Women's Microfinance Institutions Characteristic :

1. Growing up serving micro enterprises

2. Independent and free in the community;

3. Very close to the community surrounding environment

4. Have procedures borrowing without collateral;

5. Funding productive business community about the MFI's

\section{RESEARCH METHOD}

\subsection{Research Design}

This study is a combination of exploratory research, descriptive, experimental and applied research conducted in stages for the development of a comprehensive model of microfinance accommodative bebasis integrated micro business women in the district of Kota Batu. This study aims to develop a model of microfinance institutions based akamodatif women's micro-enterprises in the district of Kota Batu. The choice of location Kota Batu is a city that has a local economic development program and a microfinance institution that is currently developing in line with the vision again Kota Batu as an industrial city and Tourism. The design of this study are as follows: In this study, the "output" generated is characteristic and various obstacles / barriers to microfinance institutions that have been in Batu who focus on microenterprise development, the potential of micro enterprises and the development model of microfinance institutions accommodating based women's micro-enterprises.

\subsection{Population and Sample}

The population of this research is the Institute of Microfinance and Microenterprise Women in Batu. The sample of this research is that districts Junrejo 3 subdistrict, district and sub-district Bumiaji Stone. The details of this sample are as follow 
Jurnal Ilmiah Bidang Akuntansi dan Manajemen (JEMA) Vol. 14 No. 1 (2017)

http://riset.unisma.ac.id/index.php/jema

Table 2 Research Sample

\begin{tabular}{|r|l|c|c|c|}
\hline \multirow{2}{*}{ No } & \multirow{2}{*}{ Information } & \multicolumn{3}{|c|}{ District } \\
\cline { 3 - 5 } & & Bumiaji & Batu & Junrejo \\
\hline 1 & MFIs & 5 & 5 & 5 \\
\hline 2 & Micro Business & 10 & 10 & 10 \\
\hline 3 & Cooperation Office & \multicolumn{3}{|c|}{1} \\
\hline & Micro Business & 10 & 10 & 10 \\
\hline 4 & Women & \multicolumn{3}{|c|}{5} \\
\hline 5 & MFI Expert Opinion & \multicolumn{3}{|c|}{} \\
\hline
\end{tabular}

\subsection{Type of Data And Sampling Method}

Methods of data collection are interviews with micro businesses and focus group discussions with the management of microfinance institutions, as well as observations about the carrying capacity of the economic potential of the sub-district. While data microfinance institutions who have been there done documentation from the Office of Rural Community Empowerment in the area of research is secondary data. Descriptive analysis is used in order to describe the characteristics of a model financial institution that has existed in the district of sample areas. The sampling technique was conducted using purposive sampling (Cochran, 1991) to get a sample that can be represented. The study sample unit is a microfinance institution that has existed in the sub-districts, districts micro enterprises and informal community leaders who are concerned about the economic development districts Identify the characteristics Description Questions used for Microfinance Institutions.

1. Condition of Micro (KUM)

2. Institutional Society

3. Embryo Institutional Microfinance

4. Form and Management of Institutional Microfinance

5. Potential Business Marketing

6. The need for infrastructure Economic Infrastructure

\section{RESEARCH RESULT AND ANALYSIS}

\subsection{Descriptive of MFI's Characteristics}

\subsubsection{Year of Establishment of MFIs}

Year of establishment MFIs in Kota Batu in general is still very new categorized, given Kota Batu itself a new town by the regional growth areas, specifically the year 2001. Although the displacement of Malang has been made since the 17th of October 2001. This makes the slow development of institutions that work together to Batu compared to Malang and Malang. So that on average MFI in Batu time of its establishment over 2005

Table 3 Year of establishment of MFIs

\begin{tabular}{|c|c|c|}
\hline No & Name of MFIs & Establisment \\
\hline 1 & Wukirsari & 2010 \\
\hline 2 & Bagas bagus & 2011 \\
\hline 3 & Matahari & 2011 \\
\hline 4 & Sekawan & 2012 \\
\hline 5 & Alamanda I & 2009 \\
\hline
\end{tabular}

Source: Department of Cooperatives and SMEs Batu 2014 (processed) 


\subsubsection{Board and Board of Education MFIs}

The number of administrators for each MFI vary, For MFIs Wukirsari consists of three office bearers and the level of undergraduate education, for MFI Sun consists of five office bearers and the level of high school education, while MFI Other MFI Alamanda, Bagas Nice and Sekawan consists of one person with classification high school education.

Table 4 Board and Board of Education MFIs

\begin{tabular}{|l|c|c|c|}
\hline No & MFIs & Board & Education Official \\
\hline 1 & Wukirsari & 3 & S1 \\
\hline 2 & Bagas bagus & 1 & SMU \\
\hline 3 & Matahari & 5 & SMU \\
\hline 4 & Sekawan & 1 & SMU \\
\hline 5 & Alamanda I & 1 & SMU \\
\hline
\end{tabular}

Source: Department of Cooperatives and SMEs Batu 2014 (processed)

\subsubsection{Initial Capital Formation MFIs}

The structure of initial capital used each MFI very varied it tergantuk of aspects to be programmed, wide range of programs and the number of population density of an area. Providing capital also depends on the Institute that houses a program such as P2KP MFI (under the auspices of Infrastructure and Public Works), PNPM (under the auspices of the Minister of the Interior) and some MFIs using nongovernmental capital and assisted pemerindah area.

Table 5. Initial Capital Formation MFIs

\begin{tabular}{|l|c|c|}
\hline No & MFIs & Initial Capital \\
\hline 1 & Wukirsari & Rp. 2.952.783 \\
\hline 2 & Bagas bagus & Rp. 2.849.963 \\
\hline 3 & Matahari & Rp. 5.000.000 \\
\hline 4 & Sekawan & Rp 8.000.000 \\
\hline 5 & Alamanda I & Rp. 2.400.000 \\
\hline
\end{tabular}

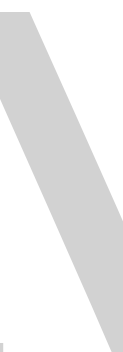

Source: Dinas Koperasi dan UMKM Kota Batu 2014 (processed)

\subsubsection{Legal Aspect MFIs}

In general, the entire existing MFIs do with the process of establishing a systematic and have a legal establishment of MFIs whether it is done with an implementation team, a village or Regulation made through notarial deed, not all MFIs have AD / ART clear unless the MFI under the auspices P2KP. Furthermore, all MFIs in the village and village Banabungi Waonu have an organizational structure and division of tasks for the MFI is still a limited number of officials and administrators that there are often double all activities.Furthermore, all MFIs have a stamp to be used as a formal legality of the transaction, whereas for the service of all MFIs do not have a special room so the room there is everything to follow the house caretaker MFI and service time varies each day.

\subsubsection{Aspects of Administration and Organization Structure MFIs}

Judging from the administrative aspects such as daily cash books, list of members, reports installment loans and card loans, loan disbursement list, report card loans and deposits as well as the complete financial statements are available at all MFIs. So also from the aspect of organizational instruments such as SK-setting board, AD / ART, the minutes of deliberation, the attendance list deliberation, proposals, proposal disbursement of funds, promissory note loans, letters of agreement, receipt equity, receipts realization of funds, account books banks, book customer lists, register of board, daily cash book, daily cash log book, cash book entry, cash book came out, the book of savings and customer lending books available in full in all MFIs. 


\subsubsection{Aspects of Development and Partnership MFIs}

Judging from the aspects of the management of MFI activities, all MFIs have (SOP) standard operating procedures are clear. Even in Bagas Good MFI borrowers do a feasibility analysis through business feasibility. Feasibility will be evaluated by the Board to obtain loan funding priorities. From the aspect of the management of other activities such as the rules on deposits and loans, the loan agreement to the borrower, billing on a regular basis, guidance to the customers, and accountability to the management of MFI forum are all available.

Meanwhile, if the review of the management of any MFI which MFIs have rules of business management respectively. For MFIs Wukirsari use guarantees a personal guarantee (joint responsibility) and buildings (because no certificate of land / area kepulawan). In addition a guarantee of jewelry and valuables. Each MFI sets an interval of relatively equal payments of less than 3 days, but if the funds are already available then the disbursement process will be faster given the funds used the turnover of funds to micro entrepreneurs who already pay.

\subsubsection{Aspects of Business Performance MFIs}

Basically the presence of microfinance institutions in the community, is expected to be the agency support group economic activities of small / micro which normally generate economic activity on a small scale, did not have a legal entity, does not have a system of administration and bookkeeping. The facts show that there is a general tendency in which the presence of microfinance institutions with good performance will have an impact on the improvement of the economic activity carried on by microenterprises. Therefore, usually microfinance institutions have special characters corresponding to their constituents, such as: 1). Consisting of some form of financial services, particularly savings and loan, 2). Directed to serve low-income communities, and 3). Using the system as well as a simple procedure. As an institution, the microfinance institutions should strive to show the failure by good business performance in order to maintain public confidence in the pegelolaan funds. Basically, microfinance institutions in the financial services it does a relatively very short and simple. For an interval of processing loans to prospective borrowers generally done in less than 3 days (on the basis of the members know the schedule of repayment and credit togethers and loan application.

\subsubsection{Needs Economic Infrastructure Support Business Support MFIs}

The development of microfinance institutions is needed in both areas, but there are many obstacles in the development of microfinance. Some of the constraints of the development of micro-finance institutions are managerial skills possessed relatively low MFI board and limited capital for MFIs, as well as many NPLs in MFIs. The conditions certainly can not be resolved properly due caretaker figure who does not understand the problems of the management of micro-finance institutions well. The condition is exacerbated by the escort role is very minimal and less active. In order to develop microfinance institutions, hence the need for supporting infrastructure for the development of MFIs is needed. MFI support infrastructure development that is required is 1) Local .Pendamping who have managerial skills to develop MFIs so it does not only depend on the government program funding. 2). Government facilitation to access additional capital for MFIs. 3). Structured and ongoing coaching of offices or banks that are committed to the development of MFIs.

\subsection{Research Discussion}

Administratively, Kota Batu is divided into three districts, and 24 villages, an area of $202.30 \mathrm{~km} 2$ (78.11 sq mi). The economic potential of the potential for development is in the sector of Agriculture, Livestock and tourism, while plantation crops include apples, strowberry, and oranges. In the tourism sector include History Attraction, Retail travel, educational travel, to the natural area. Judging from the status of enterprises SMEs, approximately $80 \%$ is a private company. Sales turnover of about $30 \%$ of respondents under 5.000.000juta per month, meaning that SMEs in Batu more as micro-enterprises. Therefore, an alternative that can be offered to encourage capital resources of SMEs is more directed at increasing services microfinance institutions. The average number of workers per unit of effort of about three people. Despite low labor education level yet large enough power SMEs. Total initial capital of 
SME respondents in the range between Rp 2 million - 8 million sourced from its own capital. This is a positive indication in terms of financial management.

On this basis, in order to encourage capital SMEs in Batu required the Microfinance Institutions can really bridge the needs of micro businesses in particular on capital. The existence of MFIs is very helpful in aspects of capital for micro entrepreneurs local in disadvantaged areas, but not all micro-entrepreneurs there can enjoy the services provided because the funds are very limited, so it takes a queue in loans, on the other hand there are many micro-entrepreneurs who do not take advantage of the presence of of local MFIs with the reason they do not know that there MFIs provide credit for SMEs, complicated procedures, no collateral and limited knowledge, is not interested in applying for a loan, do not ever apply for credit.

In a study conducted Eko Aristanto (2007) on the institutional role of microfinance community based on the Program Economic Development Zone in East Java, the sample is BKAD (Cooperation Agency, an inter-village) and micro-enterprises in 2007, there is a strategic role in the institutional BKAD the , The results showed that the presence of local institutions that have a role in providing capital for micro-enterprises in rural areas is needed. This is due to the limited access of rural micro-enterprises to formal financial institutions. Besides, the attitude powelessnes on micro- when faced with the administrative process with formal financial institutions.

This is similar Chotim research findings, E.E. and Handayani, A.D (2003) states that microfinance or microfinance, especially the informal sector, to grow roots along with the development of society. Since the days before independence, microfinance become an alternative for low-income groups to meet their funding needs. At that time, the microfinance grow and thrive in a wide range of variants suitable community needs. Basically the presence of microfinance institutions that have value alignments to micro businesses, is expected to help in addressing the issues of business (ie capital) and business management

Besides, the strategic value inherent in the function of microfinance institutions is certainly required to always keep their activities properly, as indicated by the good performance. According to Patrik. L. Romano (1989) followed Deden (2004) performance measurement (performance) is one of the processes in management control systems by comparing and evaluating the plans made and the results achieved, analyze deviations and make improvements. But if there are internal problems in microfinance institutions can result in a lower effective service on micro. Besides, the number of units of micro-finance institutions and lending procedures are relatively adaptive also influential in effective service 
Table 6 Various Potential Key Characteristics On Sample Survey Regions.

\begin{tabular}{|c|c|c|c|}
\hline Characteristics & . Bumiaji & Batu & Junrejo \\
\hline $\begin{array}{l}\text { Characteristics } \\
\text { The Main Economy }\end{array}$ & $\begin{array}{l}\text { Livestock, } \\
\text { Agriculture, } \\
\text { Trade }\end{array}$ & $\begin{array}{l}\text { Livestock, } \\
\text { Agriculture, } \\
\text { Farm }\end{array}$ & $\begin{array}{c}\text { Livestock, } \\
\text { Agriculture, Farm } \\
\text { Trade }\end{array}$ \\
\hline $\begin{array}{c}\text { Infrastucture } \\
\text { Teritory } \\
\text { Accescibility } \\
\end{array}$ & Adequate & Adequate & Adequate \\
\hline $\begin{array}{l}\text { The Main Issues - } \\
\text { Economy } \\
\text { Local }\end{array}$ & $\begin{array}{c}\text { Irigation, Low } \\
\text { Capacity } \\
\text { To Pprocess } \\
\text { Agriculte } \\
\text { Products } \\
\text { (Farm/Agriculter } \\
\text { ) }\end{array}$ & $\begin{array}{l}\text { Low Capacity } \\
\text { Low Capacity To } \\
\text { Process Local } \\
\text { Sources } \\
\text { No Representatif } \\
\text { Market }\end{array}$ & $\begin{array}{l}\text { Low Capacity } \\
\text { Local Resouces And } \\
\text { Limited Network }\end{array}$ \\
\hline Business Field Mfis & $\begin{array}{l}\text { Agricullture } \\
\text { Trade Dan } \\
\text { Livestock }\end{array}$ & $\begin{array}{c}\text { Livestock Dan } \\
\text { Processing Of } \\
\text { Livestock }\end{array}$ & $\begin{array}{c}\text { Agriculture Product, } \\
\text { Trade } \\
\text { Sembako }\end{array}$ \\
\hline Technology & (Tradisional) & Tradisional & (Tradisional) \\
\hline Management & $\begin{array}{c}\text { Family } \\
\text { (Askripsi) }\end{array}$ & Family(Askripsi) & Familiy(Askripsi) \\
\hline Source Of Capital & $\begin{array}{l}\text { Credit Mfis } \\
\text { Formal Dan } \\
\text { Informal } \\
\text { (BPR,Koperasi, } \\
\text { UPK, BKMN) }\end{array}$ & $\begin{array}{l}\text { Informal Credit } \\
\text { (LKM, Mini LKM } \\
\text { Coremap) }\end{array}$ & $\begin{array}{l}\text { Informal Credit } \\
\text { (Informal Money } \\
\text { Lender) }\end{array}$ \\
\hline Economic Orientation & $\begin{array}{c}\text { Subsisten } \\
\text { (Minimizing } \\
\text { Risk) }\end{array}$ & $\begin{array}{c}\text { Peternakan } \\
\text { (Resource Based) } \\
\text { Serta Subsisten } \\
\text { (Minimizing Risk) }\end{array}$ & $\begin{array}{c}\text { Pertanian (Resource } \\
\text { Based) Serta } \\
\text { Subsisten } \\
\text { (Minimizing Risk) }\end{array}$ \\
\hline Products Characteristic & $\begin{array}{c}\text { Non Standard } \\
\text { Quality } \\
\text { Seasonal }\end{array}$ & $\begin{array}{c}\text { Non Standard } \\
\text { Quality } \\
\text { Seasonal }\end{array}$ & $\begin{array}{c}\text { Non Standard } \\
\text { Quality } \\
\text { Seasonal }\end{array}$ \\
\hline $\begin{array}{l}\text { Pattern Social } \\
\text { Relationship }\end{array}$ & Komunal & Komunal & Komunal \\
\hline
\end{tabular}


By looking at various potentials and constraints of the existing table the main characteristics of the area, basically every region has had excellent potential and the potential of micro-enterprises. With ownership of this potential, it is to optimize the economic potential of an area locally owned, required many good efforts that include economic policy, as well as micro-economic empowerment in the region is absolutely necessary. Marketing and export orientation is a key factor in the development of the local economy, this condition is possible due to domestic market conditions are inadequate. In developing local investment, local governments must make improvements in economic policy, as much as possible to reduce high-cost economy. It is necessary for conducive policies spur the growth of your business and the incentives that encourage the influx of investors from outside the region. But in this investment policy, the local government must be careful so that investment does not disturb the economic and social conditions and culture, while on the other hand the resulting profits should be mutually beneficial investor community.

\subsubsection{Operational Design Prototype Development Microfinance Institutions}

Accommodating (Community Based On subdistrict and village levels) in Kota Batu The most important indicator in determining the success of community empowerment is the growing process of the structural changes that occur naturally. The process of structural changes naturally occur when the ability to increase local capacity significantly with an adequate increase in social welfare sustainable characterized by a progressive accumulation of capital the local level. Due to the increase and the creation of local economic activities are increasingly varied able to encourage increased demanders of money. So the money management institutions to be important in determining the occurrence of local creativity to work the local economic activities. For the presence of micro-finance institutions at the district and village levels play a role as a financial institution that can hold and manage funds rolling in the community or can be referred to as socio-economic institutions revolving fund mechanism. Expertise of local communities in resource management including capital resources in the region is the measure of success of the financial institutional system of rural communities. The success can be measured from productive economic activity is increasing. The success of MFIs in financial institutional system of rural communities can be seen from the increase in capital accumulation through accumulated savings and revolving funds to the people who do not enjoy access to capital resources. In the next stage of development, strengthening the role of MFIs is directed at strengthening the institutional function of socio-economic communities to implement development activities that are owned and executed by the local community.

At first MFI can be either economic financing institutions for local people who consciously driven managed and preserved by the people without any bureaucratic interference. The government's role is limited to providing a climate conducive to the development of wisdom and MFIs through the regulations that protect and give freedom sought for local communities. The ranks of the local bureaucracy (among others especially village government representatives and districts) need to provide "space" for the community to control the driving space MFIs them, as well as memandirikan MFIs them as financial institutions are characterized by: set / desired and owned by the community, managed by community, including its own set of system prevailing in society MFI in accordance with the aspirations and msyawarah-consensus among community members, is informal (not bound to the legal regulations of certain formal, but still follow the kaedah corresponding legal regulations existing formal) and can be utilized by all parties as well as lucrative of all parties At a later stage MFIs can develop into intermediaries (intermediarry institution) that became a bridge between the community (in the container group) with the bank institutions. In the initial status of these institutions still need to be maintained as a non-bank financial institutions and in terms of legality remains informal community-owned institution (owned jointly by the public). In carrying out roles according to their capacity and status as it is expected that the MFI mampun run a good financial administration so as to provide accurate information, complete and up to date about the financial condition of a local community in a rural area or district. Which in turn will be monitored the development of local economic and financial conditions in a region and a specific area. MFI can be interpreted also as a forum for the community to revive socioeconomic activities, 
namely through the implementation of development stats directed, coordinated and relies on community development in districts and villages.

Stabilization of MFIs is expected to strengthen the ability of planning, implementation, monitoring, financing, maintenance and development of various inputs (input) and output (output) of the development programs that reach out to the community. These include institutional strengthening, human resources (both officers and the community), facilities and infrastructure, as well as productive economic activities of society

Conditions in the field indicate the presence of micro-finance institutions in whatever form seems to be needed. It appears from the statement of the small entrepreneurs in some regions surveys tend to experience problems in managing the business of which is the business capital. On the other hand the reality shows that entrepreneurs are also difficulties and limitations in accessing credit from formal institutions. This happens due to various constraints, among others:

a. Location of rural micro entrepreneurs on average so far of dri formal institutions.

b. The business activities are still small, so the additional funds required is not too big.

c. Administrative management of the work still has not been managed well, so it does not meet the standard bookkeeping diisyarakatan formal institutions.

d. Limitations on ownership of assets that can be formally used as security (collateral)

Microfinance Institutions be an institution that is very strategic for the economic development of the people. Due to the presence of MFIs in the midst of micro-entrepreneurs who are currently still so nimin presence felt, both in terms of quality and quantity standpoint. Conceptually the activities of financial institutions always leads to the existence of institutional self embryos. Institutional independence, not only in activities but also in human resources. The presence of micro-finance institutions which can be managed well, also touch social cohesion among members of social groups was based on the confidence (trust). Close relations among members of the group and also the leadership of the successful, bringing them to help each other, share each other so that there is a reciprocal process. This is the basis for the existence of social capital in the community and at the same as the initial capital of financial institutions mikro. In order to realize the goals of local economic development is needed framework design community empowerment as a support for local economic development can be seen in the following picture:

Picture 1 MFI Community Based

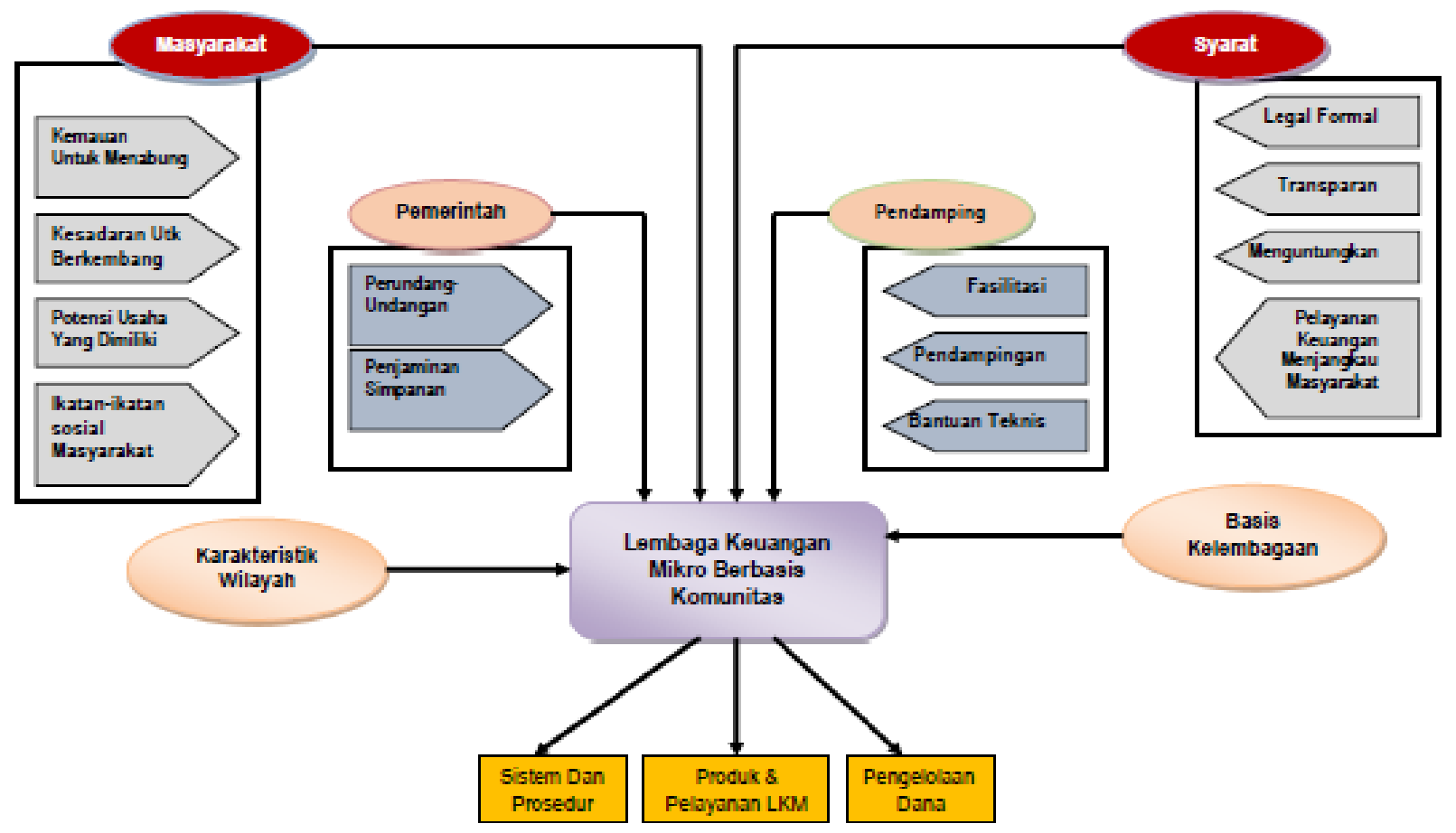




\section{RESEARCH CONCLUSION, LIMITATION, AND RECOMMENDATION}

Retrieved exploration samples thoroughly to get all the information on a selected sample of the object of Microfinance Institutions in Batu, a map of potential MFI Kota Batu, as well as the characteristics of the MFI (Year Established, Number of Board of Education and Board of MFIs, Initial Capital Formation MFI, Aspect MFI legal and administrative aspects as well as organizational instrument MFI) but it is also seen aspects of development, and partnership aspects manaemen MFIs. Retrieved design prototype model Microfinance Institutions to evaluate and seek feedback on the MFI accommodative in order to increase women's micro-enterprises based in the district of Kota Batu. Retrieved models Community Based Microfinance institutions in Kota Batu, where this model as an embryo to determine the model of microfinance institutions based on the empowerment perenpuan. Where this model needs to be disseminated are planned to be implemented in phase 2 (year 2 implementation). The shape of this activity is to find a good model (accommodating) in developing the existing MFIs in Batu by offering an alternative model created.

\section{REFERENCES}

Abdullah, Maskur. 2005. Lilitan Masalah Usaha Mikro kecil, Menengah (UMKM) dan Kontroversi Kebijakan. Medan: Bitra Indonesia.

Chotim, E.E dan Handayani, A.D, Lembaga Keuangan Mikro Dalam Sejarah, Jurnal Analisis Sosial, Volume 6, Nomor 3 Desember 2001.

Carunia,1997, Pengembangan Potensi Ekonomi Dan Pemberdayaan Ekonomi Rakyat di Biak Numfor, Irian Jaya, Analisis CSIS Tahun XXVI, Jakarta, CSIS

Cochran, G., William (1991), Teknik Penarikan Sampel (Terjemahan), Jilid III, UI-Press, Jakarta.

Deden, 2004, Analisis Strategis Bisnis dan Pengukran Kinerja Perusahaan Menggunakan Metode Balanced Scorecard, Tesis Program Magister Bisnis dan Administrasi, Sekolah Bisnis Manajemen, Institut Teknologi Bandung

Eko Aristanto,2007, Evaluasi Dampak Sosial Ekonomi Program Pengembangan Kawasan di Propinsi Jawa Timur, Universitas Merdeka Malang, LPPM

Longenecker, Justin G, Carlos W.J. \& William Petty. 2001. Kewirausahaan : Manajemen Usaha Kecil. Jakarta: Penerbit Salemba Empat.

Rian Nugraha . 2008. Pengantar Kebijakan Publik. Raja Grafindo Persada.Jakarta

Suharto, Edi. (2010) Membangun Masyarakat Memberdayakan Rakyat. Refika Aditama, Bandung

Tambunan, Tulus, T.H. 2002. Usaha Kecil dan Menengah di Indonesia Beberapa Isu Penting. Jakarta :PT Salemba Empat.

Undang-undang No. 9 Tahun 1995 Tentang Usaha Kecil.

Peraturan Pemerintah No. 44 Tahun 1997 Tentang Kemitraan.

Instruksi Presiden No. 10 Tahun 1999 Tentang Pemberdayaan Usaha Menengah.

Peraturan Pemerintah No. 32 Tahun 19998 Tentang Pembinaan dan Pengembangan Usaha Kecil.

Keppres RI No. 127 Tahun 2001 tentang Bidang/ Jenis Usaha yang Disadangkan Untuk Usaha Kecil dan Bidang/ Jenis Usaha yang Terbuka Untuk Usaha Menengah atau Besar Dengan Syarat Kemitraan.

Perda No. 10 tahun 2002 Tentang Retribusi Izin Usaha Industri, Perdagangan, Gudang/ Ruang dan Tanda Daftar Perusahaan (TDP), Dinas Perindustrian dan Perdagangan Kota Medan

*) Ike Kusdyah Rachmawati, STIE ASIA Malang 